\title{
PENINGKATAN HASIL BELAJAR MATERI BILANGAN PECAHAN MENGGUNAKAN METODE DEMONSTRASI
}

\author{
Littesy Yeristika Ersi ${ }^{1}$, Imanuel Sairo Awang ${ }^{2}$, Beni Setiawan ${ }^{3}$ \\ ${ }^{1,2}$ Program Studi Pendidikan Guru Sekolah Dasar, STKIP Persada Khatulistiwa Sintang \\ ${ }^{3}$ Program Studi Pendidikan Matematika, STKIP Persada Khatulistiwa Sintang \\ Email: ${ }^{1}$ littesye@gmail.com, ${ }^{2}$ iman.saiaw@gmail.com, ${ }^{3}$ benisetiawan1892@gmail.com
}

\begin{abstract}
This study aims to determine the increase in student learning outcomes in the topic about fraction using the demonstration method in grade IV students of SD Negeri 11 Nanga Lemetak. This research is a qualitative research with a form of research that is classroom action research (CAR) which consists of two cycles and goes through four stages, namely planning, action, observation, and reflection. The subjects of this study were grade IV students at SDN 11 Nanga Lemetak with 21 students. Data collection tools are observation sheets, test questions, interviews and documents. The results showed that: (1) Cycle I student learning activities with a percentage of $66.19 \%$ increased $11.42 \%$ to $77.61 \%$ (very good category) in the second cycle; (2) classical completeness student learning outcomes increased by $19.05 \%$ from the first cycle of $71.42 \%$ (good category) to $90.47 \%$ (very good category) in the second cycle; and (3) student learning responses to the application of demonstration methods are very good, students are more interested and focused in following the learning process. Based on the test results it can be concluded that the application of the demonstration method in mathematics, especially the material in fractions of grade IV SDN 11 Nanga Lemetak can improve student learning outcomes.
\end{abstract}

Keywords: Learning Outcomes, Demonstration, Fraction

\begin{abstract}
Abstrak. Penelitian ini dilakukan bertujuan untuk mengetahui peningkatan hasil belajar siswa pada materi bilangan pecahan menggunakan metode demonstrasi pada siswa kelas IV SD Negeri 11 Nanga Lemetak. Penelitian ini adalah penelitian kualitatif dengan bentuk penelitian yaitu penelitian tindakan kelas (PTK) yang terdiri dari dua siklus dan melalui empat tahap yaitu perencanaan, tindakan, observasi, dan refleksi. Subyek penelitian ini adalah siswa kelas IV SDN 11 Nanga Lemetak dengan jumlah siswa sebanyak 21 orang. Alat pengumpul data yaitu lembar observasi, soal tes, wawancara dan dokumen. Hasil penelitian menunjukan bahwa: (1) Aktivitas belajar siswa siklus I dengan persentase 66,19\% meningkat 11,42\% menjadi 77,61\% (kategori sangat baik) di siklus II; (2) ketuntasan klasikal hasil belajar siswa meningkat sebesar 19,05\% dari siklus I sebesar 71,42\% (kategori baik) menjadi $90.47 \%$ (kategori sangat baik)pada siklus II; serta (3) respon belajar siswa terhadap penerapan metode demonstrasi sangat baik, siswa lebih tertarik dan fokus mengikuti proses pembelajaran. Berdasarkan hasil tes dapat disimpulkan bahwa penerapan metode demonstrasi pada mata pelajaran matematika khususnya materi bilangan pecahan kelas IV SDN 11 Nanga Lemetak dapat meningkatkan hasil belajar siswa pada materi bilangan pecahan.
\end{abstract}

Kata Kunci : Hasil Belajar, Demonstrasi, Bilangan Pecahan 


\section{PENDAHULUAN}

Pembangunan

Indonesia pada hakikatnya merupakan pembangunan manusia seutuhnya dan pembangunan seluruh masyarakat Indonesia dalam segala aspek kehidupan baik yang bersifat material maupun spiritual. Unsur lain yang tidak kalah penting dalam pembangunan Indonesia ini adalah peningkatan Sumber Daya Manusia (SDM). Salah satu alternatif peningkatan sumber daya manusia adalah melalui pendidikan, sebab kehidupan dan penghidupan yang sesuai dengan nilai-nilai manusia baik secara individu maupun secara berkelompok mutlak memerlukan bekal kemampuan yang dapat dibentuk melalui jalur pendidikan.

Pendidikan merupakan suatu sistem pencerdasan anak bangsa dengan anggapan bahwa semakin terdidik seseorang, semakin tinggi juga kesadarannya terhadap segala aspek kehidupan. Dengan demikian, jelaslah bahwa pendidikan pada hakikatnya adalah suatu proses dalam upaya membangun manusia yang dapat mengenali diri dan menggali potensi yang dimilikinya serta mampu mengembangkan potensi yang ada pada diri untuk meningkatkan kualitas pendidikan. Pendidikan dapat dimaknai sebagai sebuah proses kegiatan mendidik siswa untuk menghasilkan kompetensi yang diinginkan sesuai tujuan yang ditetapkan dalam proses pembelajaran.

Pada proses pembelajaran terdapat serangkaian kegiatan untuk memberikan pengalaman belajar yang berkaitan dengan pengetahuan, keterampilan, dan sikap. Hal ini sejalan dengan pendapat Awang (2017:3) yang menuliskan bahwa, "Mengajar merupakan suatu kegiatan yang harus dilakukan guru dalam memindahkan pengetahuan (knowing), ketrampilan (skills), dan nilai (value)." Proses merupakan faktor penting untuk memperoleh hasil belajar yang baik dan memuaskan, sebagai sebuah proses maka pendidikan harus dievaluasi hasilnya untuk melihat hasil yang dicapai telah sesuai dengan tujuan yang diinginkan.

Hasil belajar adalah perubahan yang mengakibatkan manusia berubah dalam sikap dan tingkah lakunya (Winkel dalam Purwanto 2018: 45). Hasil belajar digunakan untuk menimbulkan perubahan prilaku yaitu perubahan dalam aspek kognitif, afektif dan psikomotorik. Perubahan-perubahan dalam aspek itu menjadi hasil dari proses belajar untuk semua bidang pelajaran, tidak terkecuali pada bidang studi matematika.

Bidang studi matematika merupakan bidang studi yang berguna dan membantu dalam menyelesaikan berbagai masalah dalam kehidupan sehari-hari yang berhubungan dengan hitung menghitung atau yang berkaitan dengan angka-angka. Menurut kurikulum Depdiknas 2004 (Susanto 2018: 184) disebutkan bahwa "Standar kompetensi matematika di sekolah dasar yang harus dimiliki siswa setelah melakukan kegiatan pembelajaran bukanlah penguasaan matematika, namun yang diperlukan ialah dapat memahami dunia sekitar, mampu bersaing, dan berhasil dalam kehidupan". Matematika merupakan salah satu disiplin ilmu yang dapat meningkatkan kemampuan 
berpikir dan berargumentasi, memberikan kontribusi dalam penyelesaian masalah sehari-hari dan dalam dunia kerja, serta memberikan dukungan dalam pengembangan ilmu pengetahuan dan teknologi.

Menurut Depdiknas (Susanto, 2018: 190) tujuan pembelajaran matematika di sekolah dasar adalah memahami konsep matematika, menjelaskan keterkaitan antarkonsep, dan mengaplikasikan konsep atau algoritme, menggunakan penalaran pada pola dan sifat, melakukan manipulasi matematika dalam generalisasi, menyusun bukti, atau menjelaskan gagasan dan pernyataan matematika, memecahkan masalah yang meliputi kemampuan memahami masalah, merancang model matematika, menyelesaikan model, dan menafsirkan solusi yang diperoleh, mengomunikasikan gagasan dengan simbol, tabel, diagram, atau media lain untuk menjelaskan keadaan atau masalah, memiliki sikap menghargai penggunaan matematika dalam kehidupan sehari-hari. Tujuan pembeljaran matematika tersebut diarahkan demi terciptanya hasil belajar matematika yang optimal.

Hasil belajar matematika seharusnya memberikan kesempatan bagi siswa untuk dapat terlibat langsung secara aktif pada proses pembelajaran, dengan sesuatu yang bersifat konkret maka siswa akan lebih mudah untuk terbantu dalam memahami konsep pada pembelajaran matematika. Hasil observasi awal terhadap siswa kelas IV SD Negeri 11 Nanga Lemetak dengan jumlah siswa 21 orang menunjukan bahwa hasil belajar siswa pada mata pelajaran matematika masih kurang memuaskan. Hal ini terlihat dari rata-rata hasil belajar matematika yaitu $55,71 \%$ dibawah nilai KKM pada mata pelajaran matematika di SD Negeri 11 Nanga Lemetak adalah 65.

Pada saat guru mengajar siswa terlihat kurang aktif dan tidak memperhatikan penjelasan guru, hal tersebut karena siswa merasa bosan terhadap proses pembelajaran. Metode yang digunakan oleh guru masih menggunakan metode ceramah, kesulitan guru untuk menyediakan media pembelajaran sangat terbatas sehingga proses pembelajaran kurang menyenangkan bagi siswa. Melihat kenyataan tersebut guru harus mulai memperhatikan permasalahan yang terjadi di kelas, dengan memberikan inovasi baru dalam proses pembelajaran dengan mengganti metode mengajarnya dan memberikan siswa kesempatan untuk aktif secara langsung dalam proses pembelajaran. Salah satu metode yang dapat mengembangkan keaktifan siswa yaitu metode demonstrasi.

Menurut Aqib dan Murtadlo (Astuti 2018: 43), "Metode demonstrasi adalah suatu metode mengajar dimana seorang pendidik, orang luar, atau narasumber yang sengaja diminta untuk menunjukan kepada suatu kelas suatu benda aslinya, tiruan (wakil dari benda asli) atau suatu proses." Senada dengan pernyataan tersebut, menurut Devi (2010: 8), "Metode demonstrasi adalah metode yang digunakan untuk membelajarkan peserta 
didik dengan cara menceritakan dan memperagakan suatu kegiatan-kegiatan suatu langkah-langkah pengerjaan sesuatu." Melihat permasalahan yang terjadi pada siswa kelas IV SD Negeri 11 Nanga Lemetak, peneliti tertarik untuk memberikan terobosan baru pada proses pembelajaran matematika khususnya pada materi bilangan pecahan, adapun salah satu cara meningkatkan hasil belajar siswa pada materi bilangan pecahan yakni dengan menggunakan metode pembelajaran demonstrasi sesuai dengan definisi implementasi yakni merupakan suatu proses pencapaian ide, konsep, kebijakan atau inovasi dalam suatu tindakan praktis sehingga memberikan dampak baik berupa perubahan pada kognitif, afektif dan psikomotorik siswa.

\section{METODE}

Pendekatan dalam penelitian ini menggunakan pendekatan penelitian kualitatif. Menurut Sugiyono (2013: 8), "Penelitian kualitatif merupakan suatu penelitian yang digunakan untuk meneliti pada objek yang alamiah". Hal ini dikarenakan data hasil penelitian yang diperoleh berupa kata-kata atau gambaran tentang sesuatu yang dinyatakan dalam bentuk penjelasan kata-kata atau tulisan.Metode penelitian yang digunakan oleh peneliti adalah metode demonstrasi, peneliti menggunakan metode demonstrasi guna meningkatkan hasil belajar siswa dengan memperagakan situasi atau kejadian dengan konkret.

Bentuk penelitian ini adalah penelitian tindakan kelas (Classroom Action Research).
Penelitian tindakan kelas merupakan suatu pencermatan terhadap kegiatan pembelajaran yang dilakukan dengan menggunakan alur penelitian (siklus). Dalam penelitian ini peneliti merencanakan penggunaan II siklus, setiap siklus dilaksanakan sesuai dengan perubahan yang terjadi sesuai dengan prosedur dan kriteria penelitian disekolah tersebut.Tiap siklus terdapat 4 tahapan yang dilakukan yaitu perencanaan (Planning), pelaksanaan (Action), pengamatan (Obserserving), dan refleksi (Reflecting).

Subjek merupakan pelaku atau sasaran yang akan diteliti. Subjek penelitian adalah siswa kelas IV SD Negeri 11 Nanga Lemetak.Objek atau sasaran penelitian adalah segala sesuatu yang bertalian dengan kegiatan atau proses pendidikan, yang dijadikan titik pusat perhatian atau pengamatan karena pihak peneliti ingin memperoleh informasi tentang kegiatan atau proses pendidikan tersebut. Objek dalam penelitian ini adalah metode pembelajaran demonstrasi yang dilakukan pada kelas IV. Sugiyono (2013: 38), "Variabel penelitian pada dasarnya adalah segala sesuatu yang berbentuk apa sajayang ditetapkan oleh peneliti untuk dipelajari sehingga diperoleh informasi tentang hal tersebut, kemudian ditarik kesimpulannya."

Variabel bebas dalam penelitian ini adalah penggunaan metode demonstrasi. Sedangkan variabel terikat dalam penelitian ini adalah hasil belajar siswa pada materi pembelajaran bilangan pecahan. Menurut Sugiyono (2013 :224), “Teknik pengumpulan data merupakan langkah yang paling strategis dalam penelitian, karena tujuan utama dari 
penelitian adalah mendapatkan data". Teknik pengumpulan data dalam penelitian ini adalah teknik observasi langsung, teknik pengukuran, teknik komunikasi langsung dan teknik dokumentasi. Untuk menganalisis data hasil observasi dilakukan langkah-langkah sebagai berikut:

1. Mengumpulkan hasil observasi dari observer, serta Mengolah data hasil observasi dengan teknik penskoran.

Untuk menganalisa data siswa dan lembar observasi aktivitas guru menggunakan analisis persentase skor. Untuk indikator sangat baik skor (4) baik skor (3), dengan cukup diberi skor (2), dan kurang diberi skor (1). Selanjutnya dihitung persentasenya rata-rata dengan rumus :

$$
N p: \frac{\text { Skor Perolehan }}{\text { Skor Maksimal }} \text { 100\% }
$$

Setelah diketahui hasil perhitungan persentasenya maka dimasukkan dalam analisa data yang berupa persentase menggunakan pedoman seperti terlihat pada tabel 1 .

\begin{tabular}{cc} 
Tabel 1 Kriteria Hasil Observasi \\
\hline Interval Tingkat & Kriteria \\
\hline $0 \%-25 \%$ & Kurang \\
$25 \%-50 \%$ & Cukup \\
$50 \%-75 \%$ & Baik \\
$75 \%-100 \%$ & Sangat Baik \\
\hline
\end{tabular}

Untuk mengubah skor menjadi nilai hasil belajar siswa menggunakan rumus sebagai berikut:

Nilai $=\frac{\text { jumlah skor benar }}{\text { jumlahskorkeseluruhan }} \times 100$
Adapun kriteria penilaian hasil belajar siswa dapat dilihat pada tabel 2.

Tabel 2 Kriteria Penilaian

\begin{tabular}{cc}
\hline Angka & Predikat \\
\hline $80-100$ & Sangat Baik \\
$70-79$ & Baik \\
$60-69$ & Cukup \\
$50-59$ & Kurang \\
$0-49$ & Gagal \\
\hline
\end{tabular}

\section{HASIL DAN PEMBAHASAN}

Hasil

\section{Aktivitas Guru Siklus I}

Observasi dilakukan secara langsung yang dituangkan dalam lembar observasi yang telah disediakan. Dalam penelitian ini yang menjadi observer aktivitas guru adalah wali kelas IV SD Negeri 11 Nanga Lemetak. Untuk mengetahui aktivitas guru dengan menggunakan lembar observasi, hasil observasi terhadap kemampuan guru dalam mengelola kelas dalam proses pembelajaran menggunakan metode demonstrasi dapat dilihat pada tabel 3 .

Tabel 3 Hasil Observasi Guru Dalam Mengelola Pembelajaran Siklus I

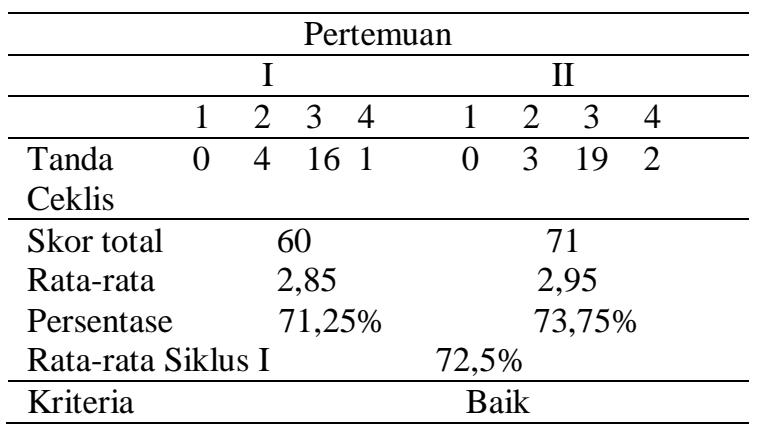

Tabel 3 menunjukkan siklus I pertemuan pertama sebesar $71,25 \%$ dengan jumlah skor total 60 kategori baik. Pada siklus I pertemuan pertama aktivitas guru dalam mengelola kelas sudah baik. Namun, harus mengatur kecepatan dalam menjelaskan materi. Pada saat 
memberikan tugas guru masih terlihat kaku dalam menjelaskaan cara menyampaikan tugas. Pada siklus I pertemuan kedua sebesar $73,75 \%$ dengan jumlah skor total 71 kategori baik. Secara keseluruhan rata-rata siklus I sebesar $72,5 \%$ dengan kategori baik. Hasil observasi siklus I menunjukan bahwa proses belajar pada siklus I belum berjalan dengan maksimal. Oleh karena itu penelitian perlu dilanjutkan pada siklus selanjutnya yaitu siklus II.

\section{Aktivitas Siswa Siklus I}

Hasil observasi aktivitas siswa dapat dilihat pada tabel 4 .

Tabel 4 Hasil Observasi Siswa Siklus I

\begin{tabular}{|lcccccccc|}
\hline Keterangan & \multicolumn{6}{c|}{ Pertemuan } \\
\cline { 2 - 9 } & \multicolumn{4}{c}{ I } & \multicolumn{6}{c|}{ II } \\
\cline { 2 - 8 } & 1 & 2 & 3 & 4 & 1 & 2 & 3 & 4 \\
\hline Tanda Ceklis & 0 & 4 & 17 & 0 & 0 & 0 & 19 & 3 \\
Skor Total & & 59 & & & 73 & \\
Rata-rata & & 2,80 & & & 3,04 & \\
Persentase & & $70 \%$ & & & $76 \%$ & \\
\hline Rata-Rata Siklus I & \multicolumn{6}{c|}{$73 \%$} \\
\hline Kriteria & & \multicolumn{5}{c|}{ Baik } \\
\hline
\end{tabular}

Tabel 4 menunjukan bahwa tingkat aktivitas belajar siswa siklus I pertemuan pertama sebesar $70 \%$ dengan jumlah skor total 59 kategori baik. Hal tersebut dikarenakan siswa masih terlihat kurang aktif, malu untuk menyampaikan pendapat dan malu untuk bertanya. Pertemuan kedua sebesar $76 \%$ dengan jumlah skor total 73 kategori baik. Hal tersebut terjadi karena siswa masih tidak memperhatikan guru menjelaskan. Rata-rata siklus I sebesar 73\%. Aktivitas belajar siswa dalam mengikuti proses pembelajaran dengan menggunakan metode demonstrasi belum berjalan dengan maksimal. Oleh karena itu peneliti perlu dilanjutkan pada siklus selanjutnya yaitu siklus II.

\section{Hasil Belajar Siklus I}

Tes siklus 1 diikuti oleh 21 orang siswa.Adapun rekapitulasi nilai hasil belajar siswa pada siklus 1 dapat diperhatikan pada tabel 5.

Tabel 5 Rekapitulasi Nilai Siswa Siklus I

\begin{tabular}{lll}
\hline No & Hasil Tes & Nilai \\
\hline 1 & Nilai Tertinggi & 100 \\
2 & Nilai Terendah & 30 \\
3 & Nilai rata-rata & 66,19 \\
4 & Nilai Klasikal & $71,42 \%$ (15 Siswa) \\
& Kategori & Baik \\
\hline
\end{tabular}

Dengan memperhatikan tabel 5 dapat diketahui bahwa nilai ketuntasan klasikal $71,42 \%$ dan belum memenuhi kriteria ketuntasan klasikasl dalam kategori baik dengan nilai KKM 65, peneliti telah memiliki target dalam penelitian dengan ketuntasan belajar klasikal siswa $80 \%$. Karena hasil belajar siswa pada siklus 1 belum mencapai target, maka peneliti melanjutkan ke siklus berikutnya yaitu siklus II.

Pertemuan pertama dilakukan pada hari selasa, 22 Oktober 2019, pukul 07.0008.10 WIB dan pertemuan kedua pada tanggal 23 Oktober 2019, pukul 07.00-08.10 WIB. Pengamatan bertujuan untuk mengetahui aktivitas belajar siswa dan kemampuan guru dalam mengelola pembelajaran.Hasil yang diamati meliputi seluruh aktivitas belajar siswa dan kemampuan guru mengelola pembelajaran.Hasil pengamatan yang diperoleh pada siklus II sebagai berikut.

\section{Aktivitas Guru Siklus II}

Hasil observasi terhadap kemampuan guru dalam mengelola pembelajaran dengan 
menggunakan metode demonstrasi dapat dilihat pada tabel 6 .

Tabel 6 Hasil Observasi Kemampuan Guru Mengelola Pembelajaran Siklus II

\begin{tabular}{|c|c|c|c|c|c|c|c|}
\hline \multirow[t]{3}{*}{ Keterangan } & \multicolumn{7}{|c|}{ Pertemuan } \\
\hline & \multicolumn{4}{|c|}{$\mathrm{I}$} & \multicolumn{3}{|c|}{ II } \\
\hline & 1 & 2 & 3 & 4 & 1 & 2 & 4 \\
\hline Tanda Ceklis & 0 & 0 & 17 & 6 & 0 & 0 & 13 \\
\hline Skor Total & \multicolumn{4}{|c|}{69} & \multicolumn{3}{|c|}{79} \\
\hline Rata-rata & \multicolumn{4}{|c|}{3,28} & \multicolumn{3}{|c|}{3,59} \\
\hline Persentase & \multicolumn{4}{|c|}{$82 \%$} & \multicolumn{3}{|c|}{$89,75 \%$} \\
\hline \multicolumn{5}{|c|}{ Rata-Rata Siklus II } & \multicolumn{3}{|c|}{$85,87 \%$} \\
\hline \multicolumn{4}{|l|}{ Kriteria } & & \multicolumn{3}{|c|}{ Sangat Baik } \\
\hline
\end{tabular}

Tabel 6 menunjukan rata-rata persentase untuk siklus II pertemuan pertama sebesar 82\%, dengan jumlah skor total 69 . Sedangkan pada pertemuan ke II sebesar $89,75 \%$ dengan jumlah skor sebesar 79, sehingga rata-rata siklus I pertemuan I dan II sebesar $85,87 \%$ dengan kriteria sangat baik. Observasi aktivitas guru dalam melaksanakan pembelajaran menggunakan metode demonstrasi, dalam pembelajaran ini aktivitas guru sudah baik dan dalam penjelasan materi sudah menggunakan bahasa yang mudah untuk siswa pahami dan guru sudah dapat menguasai kelas dengan baik.

\section{Aktivitas Siswa Siklus II}

Berdasarkan hasil observasi untuk mengetahui aktivitas siswa dalam mengikuti pembelajaran alat yang digunakan untuk mengetahui aktivitas guru dengan menggunakan lembar observasi siswa. Hasil observasi aktivitas belajar siswa dapat dilihat pada tabel 7.
Tabel 7 Hasil Observasi Siswa Siklus II

\begin{tabular}{|lcccccccc|}
\hline Keterangan & \multicolumn{6}{c|}{ Pertemuan } \\
\cline { 2 - 9 } & \multicolumn{4}{c}{ I } & \multicolumn{5}{c|}{ II } \\
\cline { 2 - 8 } & 1 & 2 & 3 & 4 & 1 & 2 & 3 & 4 \\
\hline Tanda Ceklis & 0 & 0 & 12 & 9 & 0 & 0 & 8 & 14 \\
Skor Total & & 72 & & & 80 & \\
Rata-rata & & 3,42 & & & 3,63 & \\
Persentase & & $85,5 \%$ & & $90,75 \%$ \\
\hline Rata-Rata Siklus II & \multicolumn{6}{c|}{$88,12 \%$} \\
\hline Kriteria & \multicolumn{6}{c|}{ Sangat Baik } \\
\hline
\end{tabular}

Pada tabel 7 hasil observasi aktivitas belajar siswa siklus II mengalami peningkatan, pertemuan pertama sebesar $85,5 \%$ dengan jumlah skor 72 , sedangkan pertemuan kedua sebesar $90,75 \%$ dengan jumlah skor 80 , dan rata-rata sebesar $88,12 \%$. Persentase tersebut menunjukan bahwa siswa telah maksimal dalam mengikuti pembelajaran dengan metode demonstrasi.

\section{Hasil Belajar Siklus II}

Tes siklus II diikuti oleh 21 orang siswa. Hasil belajar siswa siklus II dapat dilihat pada tabel 8 .

Tabel 8 Rekapitulasi Nilai Siswa Siklus II

\begin{tabular}{lll}
\hline No & Hasil Tes & Nilai \\
\hline 1 & Nilai Tertinggi & 100 \\
2 & Nilai Terendah & 50 \\
3 & Nilai rata-rata & 77,61 \\
4 & Nilai Klasikal & $90,47($ 19 Siswa) \\
& Kategori & Sangat Baik \\
\hline
\end{tabular}

Dengan memperhatikan Tabel 8 dapat diketahui bahwa nilai ketuntasan klasikal 90,47\% dan sudah memenuhi kriteria ketuntasan klasikal dalam kategori baik dengan nilai KKM 65, peneliti telah memiliki target dalam penelitian dengan ketuntasan belajar klasikal siswa $\geq 80 \%$. Sehingga peneliti mengambil keputusan untuk berhenti di siklus II. 
Berdasarkan hasil yang diperoleh dari pelaksanaan siklus I dalam kegiatan observasi guru dan siswa, guru sudah bisa mengatur kecepatan dalam menjelaskan materi, dan memusatkan seluruh perhatian siswa, sehingga siswa lebih aktif dan guru dapat menguasai kelas dengan baik. Guru mengatur tempat duduk siswa sehingga memastikan semua siswa memperhatikan guru, dan siswa yang ribut di beri posisi duduk paling depan sehingga hasil belajar siswa pada siklus II melakukan evaluasi sebanyak 19 siswa atau $90,47 \%$ siswa yang tuntas, hal ini mengungkapkan bahwa hasil belajar siswa sudah memenuhi indikator ketuntasan secara klasikal.

Dalam penelitian ini juga mencatat segala hal yang ditemukan dalama penerapan metode demonstrasi siklus II yaitu, (1) siswa terlihat lebih aktif dan fokus memperhatikan penjelasan guru; (2) guru selalu memberikan bimbingan dan arahan materi kepada siswa saat diskusi; (3) kegiatan pembelajaran lebih terarah dan guru dapat menyesuaikan waktu; (4) dari analisis terhadap hasil tes siklus II ketuntasan klasikal hasil belajar siswa sebesar 90,47\% terjadi peningkatan dibandingkan dengan siklus I sebesar 71,42\%, dan (5) respon belajar siswa sudah lebih meningkat dalam proses pembelajaran matematika khususnya materi bilangan pecahan menggunakan metode demonstrasi, dan pada saat proses pembelajaran siswa terlihat lebih aktif dan lebih bersemangat.

Dengan memperhatikan perolehan tersebut, maka dapat disimpulkan bahwa penggunaan metode demonstrasi dapat meningkatkan hasil belajar siswa.

\section{Perbandingan Hasil Tes Siklus I dan Siklus}

II

Hasil belajar siswa pada mata pelajaran matematika tentang bilangan pecahan di kelas IV SD Negeri 11 Nanga Lemetak mengalami peningkatan. Hal tersebut dapat dilihat dari rata-rata siklus I adalah $66,19 \%$ meningkat menjadi $77,61 \%$ pada siklus II. Kemudian disiklus I siswa yang dinyatakan tuntas belajar masih $71,42 \%$ pada siklus II meningkat menjadi 90,47\%. Hal tersebut juga dapat dilihat dari nilai terendah siklus I adalah 30 dan pada siklus II meningkat menjadi 50. Ketuntasan belajar siswa secara visual dapat dilihat pada Gambar 1.

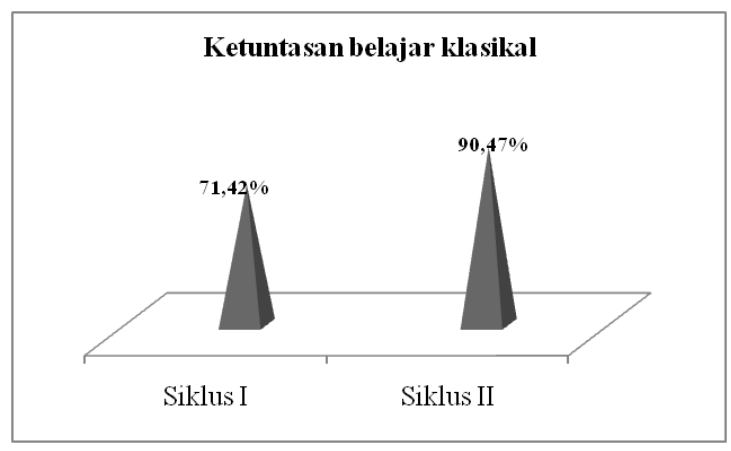

Gambar 1 Ketuntasan Belajar Siklus I dan Siklus II

Berdasarkan Gambar 1, dapat diketahui bahwa melalui penggunaan metode demonstasi perhatian siswa lebih fokus, siswa terlibat secara langsung dalam proses peragaan atau pendemonstrasian dan melalui metode demonstrasi siswa dapat menggunakan benda konkret untuk menyelesaikan masalah bilangan pecahan dalam kehidupan sehari-hari. Metode demonstrasi muncul dari konsep bahwa siswa akan lebih mudah menemukan, 
memahami, dan mengingat konsep yang sulit jika mereka melihat, mendengarkan dan melakukannya. Keterlibatan siswa dalam proses demonstrasi sangat penting, agar siswa dapat memperoleh pengelaman pribadi dari proses belajar dan memahami proses penyelesaian masalah.

\section{Pembahasan}

Hasil observasi kemampuan guru dalam mengelola pembelajaran dikelas mengalami peningkatan dengan rata-rata siklus I sebesar 72,5\% (kategori baik) dan siklus II sebesar 85, 87\% (kategori sangat baik), sehingga terjadi peningkatan sebesar 13,37\%. aktivitas belajar siswa menggunakan metode demonstrasi ditunjukan pada hasil pengamatan terhadap siswa, pada siklus I dengan rata-rata $73 \%$ (kategori baik) dan siklus II rata-rata $88,12 \%$ (kategori sangat baik) terjadi peningkatan sebesar 15,12\%. Hasil penelitian ini sejalan dengan penelitian yang dilakukan oleh Rahayu (2013), berdasarkan penelitian tersebut terdapat persamaan pada peningkatan aktivitas guru dan siswa dalam proses pembelajaran dan adanya persamaan pada variabel bebas yaitu penggunaan metode demonstrasi pada pembelajaran.

Hasil belajar siswa merupakan kemampuan yang diperoleh anak setelah mengikuti proses pembelajaran. Siswa yang mengikuti tes siklus I dan siklus II sebanyak 21 orang. Pada penelitian ini peneliti mengukur kemampuan siswa, keterampilan dan sikap siswa. Hasil belajar siswa diukur menggunakan soal tes untuk melihat hasil dari belajar siswa selama proses pembelajaran, sebelum menggunakan metode demonstrasi rata-rata hasil belajar siswa adalah $55,71 \%$ sedangkan setelah menggunakan metode demonstrasi terjadi peningkatan dari siklus I ke siklus II sebesar 20\%. Hal ini sejalan dengan penelitian Awang (2014: 112) yang menyatakan bahwa, “...hasil belajar peserta didik mengalami peningkatan setelah mengikuti proses pembelajaran dengan menerapkan metode demonstrasi."

\section{Ketuntasan Klasikal Siswa}

Ketuntasan belajar secara klasikal siswa, dan hasil belajar dilihat dari pembelajaran siklus I, hasil belajar siswa dengan KKM 65. Dari 21 siswa hanya 15 orang yang tuntas atau $71,42 \%$. Sedangkan siswa yang masih di bawah KKM atau tidak tuntas sebanyak 6 orang atau 28,57\%. Sehingga dapat disimpulkan bahwa nilai tertinggi siklus I adalah 100, nilai terendah 30, nilai rata-rata 66,19 dan ketuntasan secara klasikal 71, 42\%. Sedangkan pada siklus II hasil belajar siswa mengalami peningkatan dengan rata-rata siswa 77,61, ketuntasan secara klasikal 90,47\% nilai terendah 50 dan tertinggi 100 .

Peneliti melakukan perbaikan dengan memperbaiki strategi belajar yang digunakan guru dalam pembelajaran, dalam hal ini strategi yang digunakan guru adalah menerapkan metode demonstrasi. Hal tersebut sesuai dengan penelitian yang dilakukan oleh Mulyani (2013). Berdasarkan penelitian tersebut, terdapat persamaan pada peningkatan 
hasil belajar siswa setelah menggunakan metode demonstrasi dalam proses pembelajaran.

\section{Respon Belajar Siswa Terhadap Proses Pembelajaran dengan Menggunakan} Metode Demonstrasi

Dalam penelitian ini peneliti menggunakan teknik komunikasi langsung yaitu dengan melakukan wawancara untuk melihat respon siswa.wawancara terstruktur digunakan sebagai teknik pengumpulan data, bila peneliti atau pengumpul data telah mengetahui dengan pasti tentang informasi apa yang akan diperoleh. (Sugiyono 2013: 138). Pengetahuan yang didapat siswa setelah menggunakan metode demonstrasi pada materi bilangan pecahan bermacam-macam. Siswa tertarik untuk memperhatikan penjelasan guru, berani untuk menyampaikan pendapat, dan ada beberapa siswa yang berani untuk bertanya. Suasana kelas menjadi lebih menyenangkan karena siswa terlibat langsung dalam proses pendemonstrasian, siswa bekerjasama dengan anggota kelompok sehingga suasana kelas menjadi lebih berbeda dari sebelumnya. Kesulitan yang dialami oleh beberapa siswa adalah kesulitan dalam menggunakan alat peraga karena siswa belum mengerti cara penggunaannya.

Hal ini sejalan dengan penelitian Iyun (2017) dimana hasil penelitianya menyatakan bahwa pembelajaran matematika dengan menerapkan metode demonstrasi siswa merasa semangat, aktif, antusias, berani mengeluarkan pendapat, serta mampu bekerjasama dengan anggota kelompoknya.Persamaan dalam penelitian ini adalah terdapat peningkatan hasil belajar siswa dan respon belajar siswa setelah menggunakan metode demonstrasi, guru lebih menguasai materi dan mampu menyampaikan materi dengan baik kepada siswa.sehingga proses pembelajaran menjadi lebih bermakna bagi siswa dan memberikan manfaat yang baik bagi proses penelitian ini.

\section{SIMPULAN}

Penerapan metode demonstrasi membuat aktivitas siswa lebih efektif. Siswa mulai tertarik mengikuti proses pembelajaran dan terlihat aktif serta menyenangkan baik itu dalam kelompok maupun secara individu. Adanya peningkatan rata-rata hasil belajar siswa kelas IV SD Negari 11 Nanga Lemetak dengan mengunakan metode demonstrasi pada mata pelajaran matematika khusunya materi bilangan pecahan. Respon belajar siswa setelah menggunakan metode demonstrasi pada pembelajaran matematika khusunya materi bilangan pecahan semakin baik. Siswa terlihat aktif dan tertarik memperhatikan penjelasan guru.

\section{DAFTAR PUSTAKA}

Arikunto, 2010. Prosedur Penelitian Suatu Pendekatan Praktik. Jakarta : RINEKA CIPTA.

Astuti, T.W. 2018. Penerapan Metode Demonstrasi Untuk Meningkatkan Hasil Belajar Matematika Materi Pokok Simentri Pada Siswa Kelas V SD Negeri Sayangan No.244 Tahun Ajaran 2017/2018. Jurnal Ilmiah Konseling, 18 (1): 39-55.

Awang, I. S. 2017. Strategi Pembelajaran. Tinjauan Umum Bagi Pendidik. 
Sintang : STKIP Persada Khatulistiwa.

Awang, I. S. , \& Adpriyadi. 2014. Peningkatan Hasil Belajar Peserta Didik Menggunakan Metode Demonstrasi Pada Mata Pelajaran IPA Di Kelas Vsekolah Dasar Negeri 07 Sungai Lais. Vox Edukasi, 5(2): 100-114.

Devi, Poppy.K. 2010. Model-Model dalam Pembelajaran IPA untuk Guru SD. Jakarta: PPPPTK IPA

Iyun, 2017. Peningkatan Hasil Belajar Siswa Menggunakan Metode DemonstrasiPada Pembelajaran Matematika Di Kelas III SD Negeri 14 Batu NantaTahun Pelajaran 2016/2017. Skripsi, Sintang : STKIP Persada khatulistiwa

Mulyani, E. 2013. Penggunaan Metode Demonstrasi Untuk Meningkatkan Hasil Belajar Matematika Kelas III SDN 18 Pelangor Seluas. Jurnal Pendidikan dan Pembelajaran Khatulistiwa. 3 (4): 1-12.

Purwanto. 2018. Evaluasi Hasil Belajar. Yogyakarta : Pustaka Belajar.

Rahayu, S. 2013. Penerapan Metode Demonstrasi dan Latihan Soal Untuk Meningkatkan Hasil Belajar Matematika Siswa Kelas II. Jurnal Penelitian Pendidikan Guru Sekolah Dasar.1 (1): 1-5.

Roestiyah. 2012. Strategi Belajar Mengajar. Jakarta : PT Rineka Cipta.

Shoimin, A. 2014. 68 Model Pembelajaran Inovatif Dalam Kurikulum 2013. Yogyakarta : AR-RUZZ MEDIA.

Sudiharto. 2018. Penerapan Metode Penugasan Dan Demonstrasi Untuk Meningkatkan Keterampilan Siswa Materi Bilangan Pecahan Mata Pelajaran Matematika Kelas VI Di SD Negeri 1 Pekalongan. Jurnal Ilmiah Pendidikan Dasar, 5(1): 2833.
Sugiyono. 2013. Metode Penelitian Kuantitatif Kualitatif Dan $R \& D$. Bandung :Alfabeta.

Susanto. A. 2018. Teori Belajar Dan Pembelajaran di Sekolah Dasar. Jakarta: Prenadamedia Group. 